\title{
Prevent, Respond, Cooperate
}

\section{States' Due Diligence Duties vis-à-vis the coviD-19 Pandemic}

\author{
Antonio Coco \\ Lecturer, School of Law, University of Essex, Colchester, UK; Visiting Fellow, \\ Blavatnik School of Government, University of Oxford, Oxford, UK; Junior \\ Research Fellow, St Peter's College, University of Oxford, Oxford, UK \\ antonio.coco@essex.ac.uk
}

\section{Talita de Souza Dias}

Postdoctoral Research Fellow, Blavatnik School of Government, University of Oxford, Oxford, UK; Lecturer and Junior Research Fellow, St Catherine's College, University of Oxford, Oxford, UK talita.desouzadias@bsg.ox.ac.uk

\begin{abstract}
While disease outbreaks remain to a certain extent unforeseeable, international law provides a comprehensive legal framework requiring States to prevent their harmful consequences, effectively respond to ensuing health emergencies, and cooperate in achieving those aims. This contribution shows that, within this framework, many rules take the form of 'due diligence' obligations. Obligations of due diligence, albeit inherently flexible to accommodate different capabilities and circumstances, are binding on States. They impose a duty to act according to a standard of 'good governance': a State must employ its best efforts to realise certain common goals. At least five key sets of rules establishing due diligence duties are relevant to the coviD-19 outbreak: a) the 'no-harm' principle; b) international disaster law; c) the International Health Regulations; d) international human rights law; and e) international humanitarian law. We preliminarily identify some of the actions required from States to prevent new outbreaks and respond to the pandemic, whilst assessing compliance with applicable rules. We conclude that hard lessons learned during the current crisis should spur more decisive action to prevent and address future public health emergencies.
\end{abstract}




\section{Keywords}

due diligence - public health emergency - epidemics - prevention - mitigation cooperation - international human rights law - international humanitarian law International Health Regulations - international disaster law

\section{Introduction}

The havoc wreaked by the COVID-19 outbreak, which has so far claimed thousands of lives and threatened the collapse of health and economic systems worldwide, could have hardly been anticipated by the average person. Yet deathly epidemics have been part and parcel of the history of mankind and even though many of us grew unaccustomed to them - the occurrence of a new viral pandemic has always remained a latent possibility. ${ }^{1}$ Thus, governments have not been completely oblivious to such risk. Likewise, numerous rules of international law directly or indirectly address the prevention and response to an epidemic, with some calling for concerted action at the international level.

These rules are equally applicable to the covid-19 pandemic, imposing on States a variety of obligations before, during and after the outbreak. Many are duties of 'due diligence': obligations imposing a degree of reasonable care and analogous to domestic 'duties of care.'2 They contain a standard of conduct that measures the extent to which a State has employed its best efforts to address certain risks, threats or harms. ${ }^{3}$ In sum, 'due diligence' reflects a standard of good governance, assessing whether a State has done what was reasonably

1 See, eg, Centre for Health Security, 'The Event 201 scenario' (Center for Health Security, October 2019) <www.centerforhealthsecurity.org/event201/scenario.html> (simulating an outbreak of a novel zoonotic coronavirus); Bill Gates, 'The next outbreak? We're not ready' (TED Talk, 3 April 2015) <www.youtube.com/watch?v=6Af6b_wyiwI > (predicting the next influenza pandemic and warning about necessary measures of preparedness and resilience).

2 Study Group on Due Diligence in International Law, 'Second Report' (International Law Association, Johannesburg, July 2016) <www.ila-hq.org/index.php/study-groups?studygroupsID=63> 2 ('ILA Study'); Riccardo Pisillo-Mazzeschi, 'The Due Diligence Rule and the Nature of the International Responsibility of States' (1992) 35 GYIL 9, 40, 42; Timo Koivurova, 'Due Diligence', Max Planck Encyclopedia of Public International Law (2010) <opil.ouplaw .com/view/10.1093/law:epil/978019923169o/law-978019923169o-e1034?prd=EPIL > paras 1, 36,43 .

3 ILA Study (n 2) 22; Koivurova (n 2) paras 34-35. 
expected of it when facing harm or danger. ${ }^{4} \mathrm{~A}$ range of due diligence obligations can be found in treaties and customary international law. They apply generally to inter-State relations or specifically to fields such as the environment, human rights, international humanitarian law, cyberspace and, most notably, global public health. ${ }^{5}$ Most impose obligations of conduct, requiring States to prevent, stop and/or redress a range of internal or transboundary harms, or the risk thereof. ${ }^{6}$ But some are coupled with procedural obligations of result, such as carrying out risk assessments and sharing information. ${ }^{7}$

Due diligence obligations are inherently flexible. They depend on States' capacity to adopt the necessary and appropriate measures in light of their available technical, human and economic resources. ${ }^{8}$ This makes them particularly relevant in a world marked by inequality. States retain a wide margin of discretion when choosing appropriate measures since the extent of mandated measures depends on factors such as imminence and type of harm, available scientific knowledge and compliance with other international obligations. ${ }^{9}$ In the context of a public health crisis, health concerns must also be carefully balanced against conflicting interests, such as economic stability and development, social welfare and certain fundamental rights and freedoms. Thus, pressures of the moment and the complexity of the situation require a degree of deference to the approach taken. Nevertheless, it should be made clear that lack of capacity is no excuse; States must have in place the minimal governmental infrastructure enabling them to prevent, halt and/or redress

4 ILA Study (n 2) 1, 9, 47; Koivurova (n 2) para 16. See generally Joanna Kulesza, Due Diligence in International Law (Brill 2016); McDonald N, 'The Role of Due Diligence in International Law' (2019) 68 ICLQ 1041; Sarah Cassella (ed), Le standard de due diligence et la responsabilité internationale (Pedone, 2018).

5 ILC, 'Draft articles on Prevention of Transboundary Harm from Hazardous Activities, with Commentaries' (2001) YILC, vol II, Part Two, 148-149 ('Draft Articles on Prevention'); Koivurova (n 2 ) paras $16,23,44-45$.

6 Responsibilities and obligations of States with respect to activities in the Area (Advisory Opinion, 1 February 2011) ITLOS Reports 2011, 10 [110]-[111], [117]; Application of the Convention on the Prevention and Punishment of the Crime of Genocide (Bosnia and Herzegovina $v$ Serbia and Montenegro) (Merits) [2007] ICJ Rep 43 [430]; Koivurova (n 2) paras 1-2.

7 See Draft Articles on Prevention ( $\left.\mathrm{n}_{5}\right)$ art 7 and commentary; Certain Activities Carried Out by Nicaragua in the Border Area (Costa Rica v Nicaragua) and Construction of a Road in Costa Rica along the San Juan River (Nicaragua v Costa Rica) (Merits) [2015] ICJ Rep 665 [101], [104]; Pulp Mills on the River Uruguay (Argentina v Uruguay) (Merits) [2010] ICJ Rep 14 [94]-[122]; ILA Study (n 2) 5 .

8 ILA Study (n 2) 2, 8; Draft Articles on Prevention (n 5) 154-155, art 3(12)-(13).

9 ILA Study (n 2) 7, 9; Draft Articles on Prevention (n 5) 154, art 3(11). 
harms when required. ${ }^{10}$ This implies a baseline global standard of good governance applying to all States which, in itself, is a procedural due diligence obligation. ${ }^{11}$

In this contribution, we explore some of the key international rules which require States to act with due diligence to halt and mitigate the spread of COVID-19, as well as to prevent its further consequences and new outbreaks. First, we lay out the applicable international legal framework. Second, compliance with relevant due diligence duties is assessed thematically, according to their aims: a) preparation and capacity-building; b) monitoring and reporting; c) response and mitigation; and d) international cooperation. We conclude that hard lessons learned during the current pandemic should spur more decisive action in the future.

\section{$2 \quad$ The Legal Framework}

At least five different sets of international obligations are relevant to the CoviD-19 outbreak: a) the 'no-harm' principle; b) international disaster law; c) the International Health Regulations; d) international human rights law ('IHRL'); and e) international humanitarian law ('IHL'). In what follows, we outline the most relevant features of those regimes and demonstrate the extent to which they are applicable in the event of a pandemic and other health crises.

\subsection{The 'No-harm' Principle}

Found in customary international law, the 'no-harm' principle is a rule requiring States to take reasonable measures to prevent, stop and redress significant transboundary harm emanating from their territory or jurisdiction and affecting other States or their populations. ${ }^{12}$ It has been articulated in seminal cases such as Alabama, ${ }^{13}$ Trail Smelter, ${ }_{14}^{14}$ Nuclear Weapons Advisory Opinion, ${ }^{15}$ and Pulp Mills, ${ }^{16}$ as well as in the work of the International Law Commission ('ILC')

$10 \quad$ Draft Articles on Prevention (n 5) 156, Article 3 (17); Alabama Claims Arbitration (United States/Great Britain) (1872) 29 RIAA 125, 131; Koivurova (n 2) para 21; Pisillo-Mazzeschi (n 2) 26-27; Robert Kolb, 'Reflections on Due Diligence Duties and Cyberspace' (2015) 58 GYIL 113, 117, 127 .

11 ILA Study (n 2) 1, 47.

12 See Draft Articles on Prevention ( $\mathrm{n}_{5}$ ) art 2 and commentary.

13 Alabama (n 10) 127, 129, 131-132.

14 Trail Smelter Arbitration (United States v Canada) (1938 and 1941) 3 RIAA 1905, 1963.

15 Legality of the Threat or Use of Nuclear Weapons (Advisory Opinion) [1996] ICJ Rep 226 [29].

16 Pulp Mills ( $\left.\mathrm{n}_{7}\right)$ [197]. 
on the 2001 Draft Articles on the Prevention of Transboundary Harm. ${ }^{17} \mathrm{Al}-$ though the no-harm principle has gained most traction in the environmental realm, it applies generally in international law. ${ }^{18}$

The concept of 'harm' is broad enough to include the consequences of a disease outbreak such as COVID-19. ${ }^{19}$ The obligation requires States to act irrespective of i) who is responsible for causing the harm and ii) the lawfulness of the conduct or activity generating it. ${ }^{20}$ Thus, it covers human accidents caused by private entities and natural disasters. According to the ILC, 'significant' means 'something more than "detectable" but not necessarily "serious" or "substantial". ${ }^{21}$ The duty is triggered by both 'a low probability of causing disastrous transboundary harm or a high probability of causing significant transboundary harm'.22 There is no doubt that the CoviD-19 outbreak has caused 'significant' enough harm, including thousands of deaths and other disastrous health, economic and social consequences beyond national borders. ${ }^{23}$

As with other due diligence obligations, the no-harm principle does not impose on States a duty to successfully prevent or stop the harm from happening. Instead, it requires them to attempt to do so or to minimise the risk thereof, to the best of their abilities. ${ }^{24}$ The obligation arises from the moment States know or should have known about the harm or the risk thereof. ${ }^{25}$

\subsection{International Disaster Law}

We may intuitively associate the concept of 'disaster' with environmental catastrophes such as a tsunami or a volcanic eruption. However, the Terminology on Disaster Risk Reduction, prepared by the UN Office on Disaster Risk Reduction, lists epidemics as biological hazards susceptible of being categorized as natural disasters, whether connected to other disasters or independent from

17 See supra $\mathrm{n}_{5}$.

18 See Draft Articles on Prevention (n 5) 148-149; ILA Study (n 2 ) 6.

19 Draft Articles on Prevention (n 5) 152-153, art 2(b), (8)-(9).

20 In this way, it differs from the so-called Corfu Channel principle, which requires States 'not to allow knowingly its territory to be used for acts contrary to the rights of other States', which presupposes an internationally wrongful act. See Corfu Channel Case (Merits) [1949] ICJ Rep 4, 22.

21 Draft Articles on Prevention (n 5 ) 152, art 2(4).

22 Ibid 152, art 2(3).

23 See, eg, 'Coronavirus: the economic impact' (UNIDO, 7 April 2020) <www.unido.org/stories/coronavirus-economic-impact>; James Banks, Heidi Karjalainen and Carol Propper, 'Recessions and health: the long-term health consequences of responses to the coronavirus' (Institute for Fiscal Studies, 9 April 2020) <www.ifs.org.uk/publications/14799>.

24 Draft Articles on Prevention (n 5) 154, art 3(7).

25 Ibid 155, art 3(18). 
them. ${ }^{26} \mathrm{~A}$ similar approach is taken, among others, by the International Federation of the Red Cross. ${ }^{27}$

While a comprehensive assessment of the international legal framework on disasters ${ }^{28}$ is beyond the scope of this contribution, some key rules are enshrined in the ILC's 2016 Draft Articles on Protection of Persons in the Event of Disasters ('ILC Draft Articles on Disasters'). ${ }^{29}$ The articles may be taken to reflect customary international law or, at the very least, its progressive development in the field of risk reduction and disaster response management. ${ }^{30}$ They contain several due diligence duties of protection of persons and international cooperation with a relatively broad scope of application. Nothing in the text of the Articles suggests that an epidemic is beyond their scope, provided that it satisfies the definitional requirements under Article $3(\mathrm{a})$ of seriously disrupting the functioning of society by resulting in widespread loss of life, great human suffering and distress, mass displacement or large-scale damage, regardless of its natural or man-made source. Disasters are defined as such because of their impact, not their origin. Thus, the CoviD-19 outbreak seems to fall squarely within the definition.

\subsection{The International Health Regulations}

Issues of global health are dealt with generally in the 2005 International Health Regulations ('IHR'), ${ }^{31}$ a specialised international legal instrument adopted within the framework of the World Health Organisation ('wHo'), currently binding 196 States. $^{32}$ The IHR are especially concerned with 'public health

26 'Terminology' (UN Office on Disaster Risk Reduction) <www.undrr.org/terminology> accessed 17 April 2020.

27 'Types of disasters: Definition of hazard' (IFRC) <www.ifrc.org/en/what-we-do/disastermanagement/about-disasters/definition-of-hazard/> accessed 17 April 2020; 'Biological hazards: epidemics' (IFRC) <www.ifrc.org/en/what-we-do/disaster-management/aboutdisasters/definition-of-hazard/biological-hazards-epidemics/> accessed 17 April 2020.

'Disaster Law Database' (IFRC) < www.ifrc.org/en/publications-and-reports/idrl-data base/> accessed 17 April 2020.

29 ILC, 'Draft Articles on the Protection of Persons in the Event of Disasters, with Commentaries (2016) YILC, vol II, Part Two ('Draft Articles on Disasters').

30 See, eg, ibid art 11(3). See also Sandesh Sivakumaran, "Techniques in International LawMaking: Extrapolation, Analogy, Form and the Emergence of an International Law of Disaster Relief' (2018) 28 EJIL 1097, 1105-1106.

31 WHO, 'International Health Regulations' (adopted 23 May 2005, entered into force 15June 2007) < www.who.int/ihr/publications/9789241580496/en/> ('IHR').

32 'States Parties to the International Health Regulations (2005)' (wHO) <www.who.int/ihr/ legal_issues/states_parties/en/> accessed 17 April 2020. For a more comprehensive analysis, see Gian Luca Burci, 'The Outbreak of covid-19 Coronavirus: Are the International Health Regulations Fit for Purpose?' (EJIL: Talk!, 27 February 2020) <www.ejiltalk.org/ 
emergencies of international concern', a definition that the CoviD-19 outbreak met since its early days. ${ }^{33}$ As discussed in Section 3 below, the IHR contain a number of due diligence duties requiring States to build capacity, monitor and respond to such emergencies, as well as to prevent and contain infectious diseases.

\subsection{International Human Rights Law}

Under conventional and customary international law, States have an obligation to protect the human rights of individuals under their jurisdiction from threat or harm caused by public or private entities. ${ }^{34}$ This is yet another due diligence duty applying in situations of emergency such as the current global health crisis. Although a range of human rights are affected by the pandemic, in this short contribution we shall focus on those most directly implicated, i.e. the rights to life and health.

Whilst violations of the right to life are most commonly associated with the arbitrary use of lethal force by State authorities, public and private acts and omissions in the healthcare sector may well breach that right. ${ }^{35}$ States have a positive duty to adopt the measures necessary to safeguard the lives of individuals under their jurisdiction and to do all they can to prevent avoidable

the-outbreak-of-covid-19-coronavirus-are-the-international-health-regulations-fit-forpurpose/>. See also Pedro A Villarreal, “'Can They Really Do That?” States' Obligations Under the International Health Regulations in Light of CovID-19 - Parts I and II' (EJIL: Talk!, 31 March 2020) <www.opiniojuris.org/2020/03/31/covid-19-symposium-can-theyreally-do-that-states-obligations-under-the-international-health-regulations-in-light-ofcovid-19-part-i/>; <www.opiniojuris.org/2020/03/31/covid-19-symposium-can-they -really-do-that-states-obligations-under-the-international-health-regulations-in-light-ofcovid-19-part-ii/>.

33 'Statement on the Second Meeting of the International Health Regulations (2005) Emergency Committee Regarding the Outbreak of Novel Coronavirus (2019-NCoV)' (WHO, 30 January 2020) <www.who.int/news-room/detail/30-01-2020-statement-on-the-second -meeting-of-the-international-health-regulations-(2005)-emergency-committee-regarding-the-outbreak-of-novel-coronavirus-(2019-ncov) $>$.

34 See, eg, International Covenant on Civil and Political Rights (adopted 16 December 1966, entered into force 23 March 1976) 999 UNTS 171 (ICCPR) art 2(1); Convention for the Protection of Human Rights and Fundamental Freedoms (European Convention on Human Rights, as amended) (ECHR) art 1; African Charter on Human and Peoples' Rights (adopted 27 June 1981, entered into force 21 October 1986) (1982) 21 ILM 58 (African Charter) art 1 and Preamble, paras 1 and 10; American Convention on Human Rights (entered into force 18 July 1978) (1969) OAS Treaty Series No 36 (Pact of San Jose) art 1(1). See also Human Rights Committee ('HRC'), 'General Comment No. 31 [80]: The Nature of the General Legal Obligation Imposed on States Parties to the Covenant' (29 March 2004) UN Doc CCPR/C/21/Rev.1/Add. 1326, paras 5 and 8.

See, eg, Hristozov and Others $v$ Bulgaria ECHR 2012-V 457 [106]. 
risks thereto. ${ }^{36}$ Thus, violations of the right to life might occur in cases where an individual patient's life is knowingly put in danger by denial of access to life-saving emergency treatment, or in situations of 'systematic or structural dysfunction in hospital services.' ${ }^{37}$ Significantly, the Human Rights Committee has underlined that States' duty to protect life requires them to adopt 'appropriate measures to address the general conditions in society that may give rise to direct threats to life', including life-threatening diseases. ${ }^{38}$

Governmental responses to an epidemic even more starkly affect individuals' enjoyment of their right to the 'highest attainable standard of physical and mental health.' ${ }^{39}$ Article 12(2) of the International Covenant on Economic, Social and Cultural Rights ('ICESCR'), in particular, provides that the measures to ensure the progressive realization of the right to health include those necessary for '(c) [t]he prevention, treatment and control of epidemic, endemic, occupational and other diseases', as well as '(d) [t] he creation of conditions which would assure to all medical service and medical attention in the event of sickness'. Whilst State action is subject to technical and economic capacity or feasibility, this is no excuse for inaction. Article 2(1) of ICESCR also imposes on States obligations of immediate effect, including the duty to take deliberate, concrete and targeted steps towards the full realization of the right to health. ${ }^{40}$

$36 \quad$ LCB $v$ UK ECHR 1998-III 1 [36]; Brincat and Others $v$ Malta Apps nos. 60908/11, 62110/11, 62129/11, 62312/11 and 62338/11 (ECtHR, 24 July 2014) [79]-[8o]; cf Ximenes-Lopes v Brazil (Merits, Reparations and Costs) Inter-American Court of Human Rights Series C No 149 (4 July 2006) [89]-[9o].

37 Lopes de Sousa Fernandes v Portugal App no. 56080/13 (ECtHR, 19 December 2017) [191][192]. On this issue, see Elizabeth Stubbins Bates, 'Article 2 Echr's Positive Obligations How Can Human Rights Law Inform the Protection of Health Care Personnel and Vulnerable Patients in the Covid-19 Pandemic?' (Opinio Juris, 1 April 2020) <www.opiniojuris .org/2020/04/o1/covid-19-symposium-article-2-echrs-positive-obligations-how-can -human-rights-law-inform-the-protection-of-health-care-personnel-and-vulnerable-patients-in-the-covid-19-pandemic/>.

38 HRC, 'General Comment No. 36 (2018) on article 6 of the International Covenant on Civil and Political Rights, on the right to life' (2o October 2018) UN Doc CCPR/C/GC/36, para 26 ('General Comment No. 36 '); see also HRC, 'CCPR General Comment No. 6: Article 6 (Right to Life)' (30 April 1982), para 5, explicitly referring to the 'elimination' of 'epidemics'.

39 International Covenant on Economic, Social and Cultural Rights (adopted 16 December 1966, entered into force 3 January 1976) 993 UNTS 3 (ICESCR) art 12(1). On the link with epidemics, see Esther Pearson, 'Towards Human Rights-Based Guidelines for the Response to Infectious Disease Epidemics: Righting the Response' (2018) 24 Australian Journal of Human Rights 201.

40 Committee on Economic, Social and Cultural Rights ('CESCR'), 'General Comment No. 14: The Right to the Highest Attainable Standard of Health (Art. 12)' (11 August 2000) UN Doc E/C.12/2000/4, para 30 ('General Comment No. 14'). 


\subsection{International Humanitarian Law}

Epidemics may also occur in conflict zones, with potentially devastating effects on war-torn populations. In addition to the legal framework outlined above, States Parties to an armed conflict bear due diligence duties under I HL, ${ }^{41}$ some of which are also binding on non-State actors. ${ }^{42}$ Relevant due diligence obligations in the context of an epidemic include the duty to collect and care for the sick ${ }^{43}$ and the duty of occupying powers to ensure and maintain 'to the fullest extent of the means available' public health and hygiene measures in occupied territory. ${ }^{44}$ This last duty includes, in particular, the adoption of preventive measures to combat the spread of contagious diseases and epidemics. ${ }^{45}$

Having established the applicability of the no-harm principle, the IHR, IHRL and IHL to the COVID-19 outbreak, in this section we identify and unpack four key types of due diligence obligations which are common across all legal frameworks.

\subsection{Capacity-Building and Preparedness}

Under all frameworks surveyed above, States are required to employ their best efforts in developing the necessary capacity and preparing for a prompt and effective response to a public health emergency. First, to comply with the noharm principle, States may be required to put in place administrative policies and regulation to prevent harm from spreading to other countries. ${ }^{46}$

41 Marco Longobardo, 'The Relevance of the Concept of Due Diligence for International Humanitarian Law' (2019) 37 Wisconsin International Law Journal 44.

42 See Marcos Kotlik and Kotlik Heffes, 'Covid-19 in Conflict-Affected Areas - Armed Groups as Part of a Global Solution' (Opinio Juris, 4 April 2020) <www.opiniojuris.org/ 2020/04/04/covid-19-symposium-covid-19-in-conflict-affected-areas-armed-groups -as-part-of-a-global-solution/>.

43 Geneva Convention Relative to the Protection of Civilian Persons in Time of War (adopted 12 August 1949, entered into force 21 October 1950) 75 UNTS 287 (GC IV) common art 3; cf Jean-Marie Henckaerts and Louise Doswald-Beck, Customary International Humanitarian Law (Cambridge University Press 2005) rules 109-110 ('ICRC Study on CIHL').

44 GC IV (n 43) art 56 and commentary.

45 Ibid.

46 Draft Articles on Prevention (n 5) 154-155, art 3(10)-(11). See also arts 4 and 7. 
Likewise, they have a duty to 'reduce the risk of disasters by taking appropriate measures, including through legislation and regulations, to prevent, mitigate, and prepare for disasters' ${ }^{47}$ According to the ILC Draft Articles on Disasters, this includes 'the conduct of risk assessments' and 'the installation and operation of early warning systems', as well as contingency planning, stockpiling of equipment and supplies, arrangements for coordination, evacuation and the dissemination of public information. ${ }^{48}$ Those measures must be effective and extend throughout the situation. ${ }^{49}$

For their part, the IHR require States to 'develop, strengthen and maintain [...] the capacity to respond promptly and effectively to public health risks and public health emergencies of international concern'. ${ }^{50}$ While not requiring States to successfully put health crises to an end, this obligation imposes a due diligence duty to 'utilize existing national structures and resources to meet their core capacity requirements under [the IHR]'.51 This obligation must be implemented by, inter alia, the establishment of an emergency response plan. ${ }^{52}$

In the same vein, the positive duty to protect human life involves advance planning and immediate responses to prevent, stop or at the very least mitigate the spread of life-threatening diseases such as CoviD-19. Due diligence measures of this kind include first and foremost guaranteeing access to food, water, medicines and other objects indispensable to survival. The duty to protect life may also require effective emergency health services, emergency response operations, contingency and emergency management plans, ${ }^{53}$ or the adoption of a regulatory framework for hospitals and other health-related structures to protect patients' lives. ${ }^{54}$ As for the right to health, the Committee for Economic, Social and Cultural Rights ('CESCR') has highlighted the core duties to 'adopt and implement a national public health strategy and plan of action, on the basis of epidemiological evidence', and to 'take measures to prevent, treat and control epidemic and endemic diseases. ${ }^{55}$

In light of this comprehensive due diligence framework, it is surprising that many States were unprepared to deal with the novel coronavirus SARS-CoV-2.

47 Draft Articles on Disasters (n 29) art 9.

48 Ibid commentary to art 9 , paras $16-18$, partly citing the UN Terminology.

49 Ibid para 11.

5O IHR (n 31$)$ art 13 (emphasis added).

$5^{1} \quad$ IHR (n 31) annex 1, part A, para 1.

$5^{2}$ Ibid Public Health Response, sub (g).

53 General Comment No. 36 (n 37) para 26.

54 GN et al. $v$ Italy App 43134/05 (ECtHR, 1 December 2009) [79]-[8o].

55 General Comment No. 14 (n 40) paras 43(f) and 44(c). 
For instance, while the WHO praised China for its aggressive response to COVID-19, it noted that there were still 'areas for improvement in public health emergency response capacity'. These included overcoming any obstacles to i) act immediately on early alerts; ii) massively scale-up capacity for isolation and care; iii) optimize the protection of frontline health care workers; iv) enhance collaborative action to fill gaps in knowledge and tools; and v) more clearly communicate key data and developments internationally. ${ }^{56}$

Similarly, when the WHO declared COVID-19 a pandemic on 11 March 2020, it expressed serious concerns about its 'alarming levels of spread and severity, and $[\ldots]$ the alarming levels of inaction'. ${ }^{57}$ Nevertheless, shortages of intensive care beds, ventilators and personal protective equipment have been reported around the world, including in developed countries such as Spain, ${ }^{58}$ the United States, ${ }^{59}$ the United Kingdom, ${ }^{60}$ and in developing countries such as Iran, ${ }^{61}$ India, ${ }^{62}$ Venezuela, ${ }^{63}$ and the Central African Republic. ${ }^{64}$

56 WHO, 'Report of the wHO-China Joint Mission on Coronavirus Disease 2019 (Covid-19)' (wHO, 16-24 February) <www.who.int/docs/default-source/coronaviruse/who-chinajoint-mission-on-covid-19-final-report.pdf $>$ ('wHO-China Joint Mission Report').

57 'WHo Director-General's Opening Remarks at the Media Briefing on Covid-19' (WHO, 11 March 2020) <www.who.int/dg/speeches/detail/who-director-general-s-opening -remarks-at-the-media-briefing-on-covid-19---11-march-2020>.

58 Sam Jones, 'Spain: doctors struggle to cope as 514 die from coronavirus in a day' The Guardian (Madrid, 24 March 2020) <www.theguardian.com/world/2020/mar/24/spain -doctors-lack-protection-coronavirus-covid-19>.

59 Dennis Wagner, 'Overwhelmed hospitals, equipment shortages: Coronavirus pandemic plays out as state planners expected' USA Today (13 April 2020) <www.eu.usatoday.com/ story/news/2020/04/13/coronavirus-preparation-states-foresaw-shortages-ppe -equipment-triage-states/2974897001/>.

6o Haroon Siddique, 'What is the situation with personal protective equipment in the UK?' The Guardian (London, 14 April 2020) <www.theguardian.com/world/2020/apr/14/ coronavirus-what-is-the-situation-with-ppe-personal-protective-equipment-in-the-uk accessed>.

61 'One Dead from Coronavirus Every 10 Minutes in Iran as Shortages Forces Medics to Treat Sick without Masks' (The Independent, 19 March 2020) < www.independent.co.uk/news/ world/middle-east/coronavirus-iran-update-death-toll-medical-shortages-facemasks-a9411416.html >.

62 Ari Alstedter, 'India Finds Itself At The Back of The Line For Virus Test Kits' Bloomberg (2 April 2020) <www.bloomberg.com/news/articles/2020-04-02/india-finds-itself-at-the -back-of-the-line-for-virus-test-kits>.

63 Vanessa Silva and Katy Watson, 'Why Coronavirus Could Be Catastrophic for Venezuela' BBC News (12 April 2020) <www.bbc.com/news/world-latin-america-52204225>.

64 Neil Munshi, 'African health officials warn of chronic medical shortages' Financial Times (8 April 2020) <www.ft.com/content/72ed316a-32fb-4ae2-aa91-8885e8bbcido $>$. 


\subsection{Monitoring and Reporting}

Duties of surveillance, monitoring and notification are essential components of the legal framework requiring States to exert reasonable efforts to put in place effective emergency responses to health crises.

The IH R contains several due diligence obligations of this kind. Article 5 , for instance, provides that States must 'develop, maintain and strengthen ... the capacity to detect, assess, notify and report' manifestations of diseases or occurrences creating a potential for diseases. Those obligations shall be implemented by, inter alia, making sure that all available essential information is immediately assessed and reported at the appropriate public health levels. ${ }^{65}$ Moreover, States must assess whether a 'public health emergency of international concern' exists and, if so, to notify - efficiently and in any case within 24 hours - the wHO of the assessment and of any health measure which the State in question has already adopted in response. ${ }^{66}$ In those cases, States must also continuously share all relevant public health information with the wHO, ${ }^{67}$ even if the public health event in question is unusual or unexpected and irrespective of its origin or source. ${ }^{68}$

In the case of COVID-19, compliance with those duties first requires assessing when Chinese authorities knew or should have known the outbreak was a 'public health emergency of international concern', and how promptly this was notified to the wHO. Regardless of any alleged attempts to cover up the disease $^{69}$ or censor the spread of information, ${ }^{70}$ there are reports that local doctors had warned public authorities of a surge of unknown 'viral pneumonia' cases in mid-December $2019^{71}$ or even late November $2019 .{ }^{72}$ Given the scale and seriousness of the situation, it was at that time that a public health emergency of international concern started to unfold, even if its origin, i.e. the virus,

65 IHR (n 31) annex 1, part A, paras 4(b), 5(b) and 6.

66 Ibid art 6(1).

67 Ibid art 6(2).

68 Ibid art 7 (emphasis added).

69 Karman Lucero, 'China Responds to the Coronavirus with an Iron Grip on Information Flow' (Lawfare, 17 March 2020) <www.lawfareblog.com/china-responds-coronavirus-iron -grip-information-flow $>$.

70 'Censored Contagion: How Information on the Coronavirus Is Managed on Chinese Social Media' (The Citizen Lab, 3 March 2020) < citizenlab.ca/2020/03/censored-contagion-how -information-on-the-coronavirus-is-managed-on-chinese-social-media/>.

71 Chaolin Huang and others, 'Clinical Features of Patients Infected with 2019 Novel Coronavirus in Wuhan, China' (2020) 395 The Lancet 497.

72 Helen Davidson, 'First Covid-19 Case Happened in November, China Government Records Show - Report' The Guardian (13 March 2020) <www.theguardian.com/world/2020/ mar/13/first-covid-19-case-happened-in-november-china-government-records -show-report>. 
was only detected in late December 2019. ${ }^{73}$ Several factors that the IHR identify as evidence of a public health emergency of international concern were present at the start of the outbreak, such as treatment failure, cases reported among health staff, an event occurring in a highly populated area, an unknown underlying agent and high morbidity. ${ }^{74}$ Yet China only notified the local wHo Country Office of a possible novel coronavirus outbreak on $3^{1}$ December 2019, ${ }^{75}$ whilst the relevant information was forwarded to the organisation's headquarters on 3 January $2020 .{ }^{76}$ If those reports prove to be true, the aforementioned IHR provisions may not have been diligently followed.

The international human rights legal framework adds to these specific monitoring and reporting obligations. For instance, according to the CESCR, States must employ their 'individual and joint efforts to, inter alia, make available relevant technologies, using and improving epidemiological surveillance and data collection on a disaggregated basis.' ${ }^{77}$ In addition, 'censoring, withholding or intentionally misrepresenting health-related information' may also amount to a violation of the duty to protect the right to health. ${ }^{78}$

Those obligations arose from the moment States became aware or should have been aware of the serious health risks posed by the CoviD-19 outbreak. Therefore, to the extent that States have the necessary capacity to collect relevant data, employ appropriate technologies, disseminate crucial health information to the public and to prevent 'viral misinformation,79 they are required to do so under international human rights law. Already in February 2020, the wHO urged all States to ramp up their monitoring activity. ${ }^{80}$ It also noted that 'uncompromising and rigorous' measures such as 'extremely proactive surveillance to immediately detect cases, very rapid diagnosis and immediate case isolation, rigorous tracking and quarantine of close contacts, and an exceptionally high degree of population understanding and acceptance' were the

73 cf Villarreal (n 32) Part II, 2-3.

74 IHR (n 31) annex 2, 43-45; Huang and others (n 71).

75 'Novel Coronavirus - China' (wHO Disease outbreak news: Update, 12 January 2020) <www .who.int/csr/don/12-january-2020-novel-coronavirus-china/en/>.

$76 \quad$ wно-China Joint Mission Report (n 56) 14.

77 General Comment No. 14 (n 40) para 16.

78 Ibid para 34 .

79 See Marko Milanović, 'Viral Misinformation and the Freedom of Expression: Parts I, II and III' (EJIL: Talk!, 13-14 April) <www.ejiltalk.org/viral-misinformation-and-the-freedom-of-expression-part-i $/$ ?utm_source $=$ mailpoet\&utm_medium $=$ email\&utm campaign=ejil-talk-newsletter-post-title_2 $>$; $<$ www.ejiltalk.org/viral-misinformation-

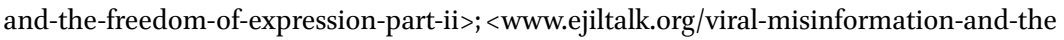
-freedom-of-expression-part-iii/>.

8 wHo-China Joint Mission Report (n 56) 19-2o. 
'only measures that are currently proven to interrupt or minimize transmission chains in humans'. ${ }^{81}$ However, deficient testing and monitoring have been reported in many States, including those with the technical, human and economic capacity to do so, such as the United States ${ }^{82}$ and the United Kingdom. ${ }^{83}$

\subsection{Response and Mitigation}

The widest and perhaps most flexible due diligence obligations applicable to a disease outbreak require States to adopt measures to contain its spread and mitigate its effects.

To begin with, in accordance with the no-harm principle, States must adopt all feasible measures to prevent or stop the transmission of the epidemic to other countries upon becoming aware of its risks or from the moment those risk became foreseeable. ${ }^{84}$ This may include a wide range of administrative or enforcement measures, which may vary on the basis of the magnitude with which the outbreak has affected their territory and the progressive development of new technologies to tackle the disease. ${ }^{85}$ In the same vein, Article 24 of the IHR requires States to take all practicable measures to ensure that entities in charge of international transport and travel 'comply with the health measures recommended by the WHO and adopted by the State Party, [...] inform travellers of the [said] health measures [...] and [...] permanently keep [means of transport] for which they are responsible free of sources of infection or contamination'. The implementation of any health measure in this respect must be based on scientific principles, available scientific evidence and any available guidance, advice or information provided by wно. ${ }^{86}$

To the extent that the CoviD-19 outbreak amounts to a disaster, States have a best-efforts obligation to 'ensure the protection of persons and provision of disaster relief assistance in [their] territory, or in territory under [their] jurisdiction or control'. ${ }^{87}$ They must also take all appropriate measures to ensure

81 Ibid 19 (emphasis added).

82 Abby Goodnough, Katie Thomas and Sheila Kaplan, 'Testing Falls Woefully Short as Trump Seeks an End to Stay-at-Home Orders' The New York Times (15 April 2020) <www .nytimes.com/2020/04/15/us/coronavirus-testing-trump.html>.

83 Frances Perraudin and Pamela Duncan, 'Britain's coronavirus testing scandal: a timeline of mixed messages' The Guardian (3 April 2020) <www.theguardian.com/politics/2020/ apr/o3/coronavirus-testing-in-uk-timeline-of-ministers-mixed-messages>.

84 Draft Articles on Prevention ( $\mathrm{n}_{5}$ ) art 3(18).

85 Ibid art 3(6), (10)-(11); Deep Seabed Mining Advisory Opinion (n 6) [117]; ILA Study (n 2) 12.

86 IHR (n 31) art 43(2).

87 Draft Articles on Disasters (n 29) art 10(1). 
the protection of external relief personnel, equipment and goods under their jurisdiction. ${ }^{88}$

Under IHRL, along with the provision of items essential for individual subsistence, personal protective equipment and emergency health services, as discussed above, ${ }^{89}$ States must establish 'prevention and education programmes for behaviour-related health concerns' ${ }^{90}$ As covid-19 is known to be highly contagious, behaviour-related health concerns range from basic hygiene to any social activity that requires close human contact or interaction. This means that educational campaigns about hand-washing, social distancing and staying at home may be required not only by wisdom and medical necessity but also by law. Measures to protect and ensure the right to health may also include the implementation or enhancement of immunization programmes and other strategies of infectious disease control. ${ }^{91}$ Importantly, the duty to ensure the right to health presupposes, at a minimum, an obligation to put in place an effective system of urgent medical care to cope with the life-threatening consequences of the pandemic..$^{92}$

In conflict zones, all parties to the conflict have a general due diligence obligation to care for the sick, ensuring that they receive the required medical attention to the fullest practicable extent. ${ }^{93}$ This duty is heightened for occupying powers which have an obligation to ensure and maintain, to the fullest available extent, 'medical and hospital establishments and services, public health and hygiene in the occupied territory, with particular reference to the adoption and application of the prophylactic and preventive measures necessary to combat the spread of contagious diseases and epidemics. ${ }^{94}$

Yet, in the first few weeks following the outbreak, slow government responses have been recorded around the world. For instance, in the United States, the

88 Ibid art 16.

89 General Comment No. 36 ( $\mathrm{n}_{38} 8$ para 26.

9o General Comment No. 14 (n 40) para 16.

91 Ibid.

92 Ibid. On the minimum core obligations, see also Tim Fish Hodgson and Ian Seiderman, 'Covid-19 Responses and State Obligations Concerning the Right to Health (Part 2)' (Opinio Juris, 1 April 2020) <www.opiniojuris.org/2020/04/01/covid-19-symposium -covid-19-responses-and-state-obligations-concerning-the-right-to-health-part-2/>.

93 GC IV common art 3; ICRC, Commentary of 2016, paras $761 \mathrm{ff}$., especially para 762 ; cf Protocol Additional to the Geneva Conventions of 12 August 1949, and relating to the Protection of Victims of Non-International Armed Conflicts (adopted 8 June 1977; entered into force 7 December 1978) 1125 UNTS 609 art 7(2); and ICRC Study on CIHL (n 43) rule 110.

94 GC IV art 56. cf Marco Longobardo, 'The Duties of Occupying Powers in Relation to the Fight against Covid-19' (EJIL: Talk!, 8 April 2020) <www.ejiltalk.org/the-duties-of -occupying-powers-in-relation-to-the-fight-against-covid-19/>. 
first case was confirmed on 21 January 2020. ${ }^{95}$ However, it was only on 21 March 2020 that the country's Food and Drug Administration gave emergency approval to a test that could diagnose CoviD-19 more quickly. ${ }^{96}$ At the time of writing, the United States federal administration is yet to impose containment measures, leaving them at the mercy of state governors. ${ }^{97}$ Similarly, the Brazilian president has openly dismissed some of the official warnings about the virus, including from his own health minister who was eventually sacked. ${ }^{98}$ It was individual states and municipal authorities that took the lead in adopting quarantine and other emergency measures. ${ }^{99}$

In Italy, it took the government several weeks after the first cases were identified to recommend measures of social distancing, ${ }^{100}$ quarantine and travel restrictions. ${ }^{101}$ It was only when the number of cases had spiralled to over fifteen thousand and the death toll to over a thousand that the Italian Prime Minister declared a national emergency and a country-wide lockdown. ${ }^{102}$ Considering the potential impact of those measures on the national economy and social life, some time was needed to evaluate their effectiveness and minimise their impact. However, the example of China and other States heavily affected by the outbreak could perhaps have been followed more promptly, as advised by the WHO. ${ }^{103}$

95 'Cases in U.S.' (Center for Disease Control and Prevention, 16 April 2020) <www.cdc.gov/ coronavirus/2019-ncov/cases-updates/cases-in-us.html>.

96 'Coronavirus (COVID-19) Update: FDA Issues first Emergency Use Authorization for Point of Care Diagnostic' (FDA News Release, 21 March 2020) <www.fda.gov/news-events/ press-announcements/coronavirus-covid-19-update-fda-issues-first-emergency-use -authorization-point-care-diagnostic $>$.

97 Tom McCarthy, 'US states improvise rules to combat coronavirus in absence of federal leadership' The Guardian (17 March 2020) <www.theguardian.com/world/2020/mar/17/ us-states-improvise-coronavirus-trump-federal-leadership-absent>.

98 Katy Watson, 'Coronavirus: Bolsonaro fires health minister over pandemic response' BBC News (São Paulo, 16 April 2020) <www.bbc.co.uk/news/amp/world-latin-america $-52316150>$.

99 Tom Philipps and Don Philipps, 'Bolsonaro dragging Brazil towards coronavirus calamity, experts fear' The Guardian (Rio de Janeiro, 12 April 2020) <www.theguardian.com/ world/2020/apr/12/bolsonaro-dragging-brazil-towards-coronavirus-calamity -experts-fear>.

100 'Coronavirus: Italy extends emergency measures nationwide' $B B C$ News (10 March 2020) $<$ www.bbc.co.uk/news/world-europe-51810673>.

101 Rachel Donadio, 'Italy's Coronavirus Response Is a Warning From the Future' The Atlantic (8 March 2020) <www.theatlantic.com/international/archive/2020/o3/italy-coronavirus -covidig-west-europe-future/60766o/>.

102 Marc Lowen, 'Coronavirus: Italy says 1,00o have died but lockdown can work' BBC News (Rome, 12 March 2020) <www.bbc.co.uk/news/world-europe-51852320>.

103 WHO-China Joint Mission Report (n $\left.5^{6}\right)$ 14-15. 
A similar delay to act may be observed in other countries. One may query whether some States have seriously downplayed the gravity of the outbreak and the disease. For instance, in the United Kingdom, the government was initially hesitant to follow the WHO's advice to adopt more rigorous measures, wary as it was of their significant economic impact. ${ }^{104}$ It was only following serious criticism ${ }^{105}$ that the government started to gradually 'recommend' more impactful measures, such as working from home, social distancing and restrictions on social gatherings. ${ }^{106}$ The death toll had already surpassed 200 when schools and some London underground stations were closed. ${ }^{107}$ Restaurants, cafés, pubs, and 'leisure centres' were only officially required to shut down on 20 March 2020, ${ }^{108}$ before the government eventually adopted a full lockdown strategy on 23 March $2020 .{ }^{109}$ Yet, at that time, it was already foreseeable this was a risky move that could (and eventually did) lead to widespread contamination in London and other densely populated areas. ${ }^{110}$

104 Sarah Boseley, 'Herd immunity: will the UK's coronavirus strategy work?' The Guardian (13 March 2020) <www.theguardian.com/world/2020/mar/13/herd-immunity-will-theuks-coronavirus-strategy-work $>$; Laura Oliver, 'Most people see covid-19 as an economic crisis first, health risk second, survey finds' (World Economic Forum, 18 March 2020) $<$ www.weforum.org/agenda/2020/03/covid-19-public-perception-economic-health-crisis -coronavirus-pandemic-ipsos/>.

105 Heather Stewart and Mattha Busby, 'Coronavirus: science chief defends UK plan from criticism' The Guardian (13 March 2020) <www.theguardian.com/world/2020/mar/13/ coronavirus-science-chief-defends-uk-measures-criticism-herd-immunity>; Pallab Ghosh, 'Coronavirus: Some scientists say UK virus strategy is "risking lives"' $B$ BC News (14 March 2020) <www.bbc.co.uk/news/science-environment-51892402>.

106 Sarah Boseley, 'New data, new policy: why UK's coronavirus strategy changed' The Guardian (16 March 2020) <www.theguardian.com/world/2020/mar/16/new-data-new-policy -why-uks-coronavirus-strategy-has-changed $>$.

107 'Coronavirus: 40 London Underground stations to be closed' $B в C$ News (19 March 2020) <www.bbc.co.uk/news/uk-england-london-51946409>; 'Coronavirus: UK schools, colleges and nurseries to close from Friday' $B$ B News (18 March 2020) <www.bbc.co.uk/news/ uk-51952314>.

108 Heather Stewart and Peter Walker, 'Coronavirus UK: Boris Johnson announces closure of all UK pubs and restaurants' BBC News (21 March 2020) <www.theguardian.com/ world $/ 2020 / \mathrm{mar} / 20 /$ london-pubs-cinemas-and-gyms-may-close-in-covid-19 -clampdown $>$.

109 'Staying at home and away from others (social distancing)' (United Kingdom Cabinet Office, 23 March 2020) <www.gov.uk/government/publications/full-guidance-on-staying-at -home-and-away-from-others>.

110 See Adrian Sherling, 'Former Chief Scientific Adviser: Austerity and delay has led to more people dying' LBC Radio (15 April 2020) <www.lbc.co.uk/radio/presenters/nick-ferrari/exchief-scientific-advisor-austerity-coronavirus/>; Rowena Mason, 'Boris Johnson reacted 


\subsection{International Cooperation}

Lastly, States must exercise due diligence in genuinely cooperating with other States and international institutions in the context of a pandemic that has rapidly spread across territorial boundaries. ${ }^{111}$ This is so to the extent that concerted international action is not only possible but also necessary to tackle this global problem. As powerfully expressed by the former UK Prime Minister Gordon Brown:

We've had too much of America first, India first, China first. We are finding that we depend on each other, whether we like it or not. [...] [P]eople have got to put aside the differences they have and international cooperation is absolutely vital to this.

Specifically, Article 44 of the IHR establishes a general obligation to cooperate not only with the WHO itself but also with other States to the extent possible to i) detect, assess and respond to public health emergencies; ii) develop, strengthen and maintain public health capacity; and iii) mobilize financial resources. By the same token, Article 15 of the ILC Draft Articles on Disasters requires States to take the necessary measures under national law to facilitate the prompt and effective provision of external assistance. Article 11 of the same instrument stipulates a corresponding duty to seek international assistance by the time States realise that the containment of the disease manifestly exceeds their national capacity. Similarly, in situations of armed conflict, parties must 'allow and facilitate rapid and unimpeded passage of humanitarian relief for civilians in need', including medical assistance and equipment. ${ }^{112}$ Human rights treaty bodies have also stressed the need for international cooperation. In particular, States which are in a position to assist other States struggling to meet their core obligations must render them reasonable assistance. ${ }^{13}$

too slowly to CoviD-19, says former scientific adviser' The Guardian (15 April 2020) <www .theguardian.com/politics/2020/apr/15/boris-johnson-reacted-too-slowly-to-covid19-says-ex-scientific-adviser>; Rowena Mason, 'Coronavirus: London hospitals facing 'tsunami' of patients' The Guardian (26 March 2020) <www.theguardian.com/world/2020/ mar/26/london-hospitals-facing-tsunami-of-coronavirus-patients-overwhelmed $>$.

111 Lizzy Buchan, 'Coronavirus: Gordon Brown says too much 'populist nationalism' in fight against outbreak' The Independent (19 March 2020) <www.independent.co.uk/news/uk/ politics/coronavirus-uk-cases-update-gordon-brown-populist-nationalism-a9410496 .html>.

112 cf ICRC Study on CIHL (n 43) rule 55; GC IV art 55, for occupying powers.

113 General Comment No. 14 (n 40) para 45. 


\section{Conclusion}

It is quite clear that this is not the last epidemic we will have to face. Whether it is another coronavirus, a flu pandemic or a brand-new disease, we must be prepared to prevent and mitigate it, particularly through monitoring and international cooperation. As this contribution has shown, a comprehensive yet flexible international legal framework must be followed in the event of an epidemic. This framework requires States to prepare for disease outbreaks, spot their early signs and respond effectively in a concerted way. The message of international law is clear: prevention is better than cure, and States must do their best to achieve this objective, including by cooperating. The apology expressed by the President of the European Union Commission to Italy, for having failed to timely provide help from the beginning of the outbreak, epitomizes the cardinal place that preparedness, responsiveness and solidarity hold at the core of any strategy against a public health emergency of these proportions. ${ }^{114}$ Although COVID-19 has already caused a great deal of irreversible damage to the functioning of our societies, we must hope that lives and livelihoods were not lost in vain. May we learn from our mistakes and act now, to avert bigger losses tomorrow.

\section{Acknowledgements}

This article builds on a 3-part blog series published by the authors on EJIL: Talk! on 24-25 March 2020.

114 'Speech by President von der Leyen at the European Parliament Plenary on the EU coordinated action to combat the coronavirus pandemic and its consequences' (European Commission, 16 April 2020) <ec.europa.eu/commission/presscorner/detail/en/speech _20_675>. 